\title{
DRY POWDER FORMULATION FROM PHYSALIS PERUVIANA L. FRUITS EXTRACT WITH ANTIDIABETIC ACTIVITY FORMULATED VIA CO-SPRAY DRYING
}

\author{
CARLOS A. BERNAL ${ }^{\mathrm{a}, \mathrm{b}}$, FREDDY A. RAMOS ${ }^{\mathrm{c}}$, YOLIMA BAENA ${ }^{\mathrm{a}^{*}}$
}

aUniversidad Nacional de Colombia-Sede Bogota-Science Faculty-Pharmacy Department-Research Group Technology of Natural Products-Carrera 30 \# 45-03, Bogotá D. C., (111311), Colombia, bUniversidad de Cartagena-Faculty of Pharmaceutical Sciences-Research Group Tecnología Farmacéutica, Cosmética y de Alimentos (GITFCA). Zaragocilla, Calle 29 \# 50-50, Cartagena, Bolívar (130014), Colombia, cUniversidad Nacional de Colombia-Sede Bogotá-Science Faculty-Chemistry Department-Research Group Estudio y aprovechamiento de productos naturales marinos y frutas de Colombia-Carrera 30 \# 45-03, Bogotá D. C., (111321), Colombia Email: ybaenaa@unal.edu.co

Received: 05 Sep 2018, Revised and Accepted: 05 Mar 2019

ABSTRACT

Objective: To establish the drying conditions of an extract of fruits of Physalis peruviana using spray drying (SD) technique by applying a statistical experimental design (SED), to obtain powders for direct compression, retaining the antidiabetic activity.

Methods: A 2[6-2] fractional factorial SED was used to get a suitable SD operating conditions to produce powder extract of P. peruviana with high process yield, acceptable moisture content, good flowability, low hygroscopicity and satisfactory morphological and particle size. Operating variables studied were air inlet temperature, atomization air flow rate, feed-rate pump, aspiration rate, extract concentration and coadjuvant proportion. P. peruviana powder obtained under the operating conditions selected was evaluated by X-ray powder diffraction (XRPD), differential scanning calorimetry (DSC) and by in vitro $\alpha$-amylase inhibition assay, to prove that the antidiabetic activity was remained after the SD.

Results: Injection temperature $\left(120^{\circ} \mathrm{C}\right)$, atomization air flow rate $(600 \mathrm{l} / \mathrm{h})$, pump setting $(5 \%)$, aspirator setting $(100 \%)$, extract concentration $(7.5 \% \mathrm{p} / \mathrm{p})$ and extract: coadjuvant ratio (1:0.75), were the operational conditions selected. Dry extract showed an amorphous state by XRPD and a probable protective effect of coadjutant on the extract, characterized by DSC and the antidiabetic in vitro assay. Antidiabetic activity of the extract remained after its transformation to a solid state by SD in the chosen conditions.

Conclusion: The results suggest that coprocessed extract could be used for the production of compressed solids or employed as an intermediate herbal product for the treatment of diabetes.

Keywords: Physalis peruviana. Pharmaceutics properties, Statistical experimental design, Spray drying, Herbal product, Antidiabetic activity

(C) 2019 The Authors. Published by Innovare Academic Sciences Pvt Ltd. This is an open access article under the CC BY license (http://creativecommons.org/licenses/by/4.0/) DOI: http://dx.doi.org/10.22159/ijap.2019v11i3.29520

\section{INTRODUCTION}

Physalis peruviana, of Solanaceae family, is popularly known in Colombia as cape gooseberry, uchuba, uchubo, among others common names and its fruits are used as food and various parts of the plant are employed for medicinal purposes [1-3]. The fruits are popularly used for the prevention and treatment of pterygia, as an expectorant, diuretic and anthelmintic, for the treatment of diabetes, albuminuria and pertussis, as well as for teeth strengthen. It is well known that daily consumption of raw fruits of $P$. peruviana helps to maintain stable glucose level in blood [3-6]. Several other uses, some of them supported by pharmacological studies, have been attributed to calyxes $[7,8]$, leaves [3], roots [9], and even for the whole plant [2, 10-13]. Recently, we described peruvioses $\mathrm{A}-\mathrm{F}$ as the main compounds present in the sticky exudate of the fruits, and the responsible for the observed in vitro $\alpha$-amylase inhibition activity [14].

P. peruviana ethanolic extract showed the following technology difficulties: high hygroscopicity, reduced flow properties, high cohesivity and low compressibility. Changes in physical state could contribute to improving its properties. In a previous job, dry powder formulation from standardized extract of the fruit was reported to have hypoglycemic activity and their characteristics were established to have a material that can be used as a solid dosage form [3]. However, the dried process (in oven) influences the chemical stability and its hypoglycemic activity, according to studies made in our laboratories. For that reason, SD technique represents a better option for this extract [3].

The design of a SD process includes setting the operating conditions that favor the yield increase and generates a product with predefined quality specifications [15-19]. Some of the most relevant properties of the dried extracts are particle and distribution of particle size, particle shape, density and porosity, flowability, moisture content, and hygroscopicity, appearance and texture of the material obtained [20-24].
The aim of this work was to establish the drying conditions of the $P$. peruviana fruit ethanolic extract using a SD technique to obtain extract powder for direct compression (DC) or to be employed as an intermediate herbal product, without losing activity.

\section{MATERIALS AND METHODS}

\section{Materials}

P. peruviana fruits were collected in Subia, Cundinamarca, Colombia in January 2013. A voucher specimen of the plant (574701) was identified and deposited at the Herbario Nacional Colombiano of the Universidad Nacional de Colombia. Ethanol (EtOH) $96 \%$ (produced by Empresa de Licores de Cundinamarca-Colombia, Pharmaceutical grade) was used for the preparation of fluid plant extracts. Silicon dioxide (Aerosil 200®, Degussa AG, Pharmaceutical grade) was used as coadjuvant in the drying process. To the development of the hypoglycemic in vitro assay, acarbose (Sigma/Aldrich A8980), porcine pancreatic alpha-amylase (PPA) (Sigma/Aldrich A3170) and Blue Starch (Sigma/Aldrich S7776) were used.

\section{Preparation of the fluid extract}

The entire fruits of $P$. peruviana were weighted accurately (5000 g), liquefied, dried $\left(40^{\circ} \mathrm{C}\right)$ and triturated as previously was described by us [3]. The powder obtained was extracted with EtOH by percolation method, with continuous additions of solvent. The extraction stage was carried out for $4 \mathrm{~d}$, with a drug: solvent ratio of 1:15. The extract was concentrated under vacuum with a rotary evaporator (IKA® RV-10) until to obtain the fluid extract. The concentration was determined by a calibration curve of refractive index vs. total solid content. The refractive index was determined using a digital refractometer (30PX Mettler Toledo) and the total solid content was obtained by weighting the dried extract, followed by freeze-drying and extract reconstitution in ethanol to obtain each concentration. 


\section{Preparation of spray dried extract: statistical experimental design}

The spray dried extract was obtained using the SD equipment (Buchi mini spray dryer B-290 with the dehumidifier and Inert Loop B 295 for drying organic solvents), connected to a nitrogen generator to produce inert gas as atomization air. The drying conditions of extract were established according with variables (factors A to $\mathrm{F}$, according with table 1): injection temperature, atomization air flow rate, pump setting, aspirator setting, extract concentration and coadjuvant proportion, in two levels.

Table 1: Operating variables levels

\begin{tabular}{llll}
\hline Variable & Low level (-) & High level (+) & Units \\
\hline (A) Injection temperature & 80 & 120 & ${ }^{\circ} \mathrm{C}$ \\
(B) Atomization air flow rate & 400 & 600 & $1 / \mathrm{h}$ \\
(C) Pump setting & 5 & 15 & $\%$ \\
(D) Aspirator setting & 80 & 100 & $\%$ \\
(E) Extract concentration & 5.00 & 10.00 & $\%(\mathrm{w} / \mathrm{w})$ \\
(F) Coadjuvant proportion & $1: 0.5$ & $1: 1$ & - \\
\hline
\end{tabular}

A factorial experimental design type 2[6-2] was used and is shown in table 2, to determinate the effect of the operating variables (Factors A to F) on pharmaceutical properties of the obtained dried extract. 16 runs were required.

Table 2: Experimental matrix according with $2^{6-2}$ factorial design

\begin{tabular}{|c|c|c|c|c|c|c|}
\hline Run & $\mathbf{A}$ & B & $\mathrm{C}$ & D & $\mathbf{E}$ & $\mathbf{F}$ \\
\hline 1 & - & + & - & + & + & - \\
\hline 2 & + & - & - & + & + & - \\
\hline 3 & - & + & - & - & - & + \\
\hline 4 & - & - & - & + & - & + \\
\hline 5 & + & + & - & - & + & - \\
\hline 6 & + & - & + & - & + & - \\
\hline 7 & - & - & - & - & + & + \\
\hline 8 & + & - & + & + & - & + \\
\hline 9 & + & - & - & - & - & - \\
\hline 10 & - & + & + & - & + & - \\
\hline 11 & + & + & - & + & - & + \\
\hline 12 & - & + & + & + & - & + \\
\hline 13 & - & - & + & - & - & - \\
\hline 14 & + & + & + & + & + & - \\
\hline 15 & + & + & + & - & - & + \\
\hline 16 & - & - & + & + & + & + \\
\hline
\end{tabular}

\section{Sample preparation and characterization prior to SD process}

Fluid extract at the defined concentration and silicon dioxide (drying coadjuvant), were used as ingredients for the SD process, [18, 25-29] in the proportion established by the SED (table 2). The suspension obtained was stirred to homogenize the dispersion for $30 \mathrm{~min}$ (magnetic stirrer IKA C-MAG HS 7); the stirring was maintained during the process. Viscosities of these mixtures obtained were determined. The viscosities of the samples were evaluated by triplicate at $20{ }^{\circ} \mathrm{C}$ using a Brookfield DV-E viscometer, with a Spin-05 and 50 RPM.

After sample characterization, SD process was carried out for 16 runs. The following response variables were evaluated:

\section{Process yield}

The yield of the SD process for each experiment was calculated as the ratio of the weight of the dry powder obtained and the initial total solids (extract+coadjuvant) in the suspension prepared.

\section{Moisture content}

The moisture content of the powders was determined in a moisture balance Geheka IV-2000. Samples measurements were determined immediately after finished the SD process, the determination was made by triplicate with 3 samples each one.

\section{Physical-mechanic properties}

\section{Particle morphology and size and particle size distribution}

Analysis of particle shape was performed by scanning electron microscopy (SEM) [30], and optical microscopy method as was described by USP 40 and Martin et al. [31], for size and particle size distribution [30]. For determining the particle size, a total of 500 particles distributed in 10 samples were evaluated. The samples were taken from different parts of the material from which the information of the diameter was obtained and analyzed by means of the Motic Image plus 2.0 software. The volume-surface mean diameter was calculated according to equation 1 where " $n$ " is the number of particles in each range and " $\mathrm{d}$ " is the mean of size range in micrometers [31].

$$
d_{v s}=\frac{\Sigma n d^{g}}{\sum n d^{2}}
$$

(Equation 1)

\section{Angle of repose}

The flow properties of the materials were determined by the static method based on the measuring of the repose angle. For this determination, $5 \mathrm{~g}$ of material was weighed and placed through a funnel positioned at a fixed height on a graph paper flat horizontal surface and allowing this form a cone, measuring the height $(\mathrm{h})$ and radius ( $r$ ). The tangent of the angle of repose is given by the expression $\mathrm{h} / \mathrm{r}$ ratio [8]. Five repetitions were done in triplicate for a total of fifteen data.

\section{Bulk and tap densities}

To determine the density of samples the method described by Bernal et al. was used [3]. For this procedure, an amount of material equivalent to a volume between 4 to $5 \mathrm{ml}$ was placed gently into a 5 $\mathrm{ml}$ graduate cylinder certified, and then measuring the weight and the volume occupied by it, to determine the Bulk density (BD). Next, the material was tapped 1000 times using the tap density equipment JV-1000 Copley, and subsequently, the volume occupied was measured, to calculate the Tap density (TD). Five replicates were performed in triplicate for a total of fifteen dates. The compressibility of the material was assessed using Carr's compressibility index $(\mathrm{CI})$ shown in equation 2. 


$$
C I=\left(\frac{B D-T D}{B D}\right) 100
$$

(Equation 2)

\section{Hygroscopicity}

Samples of $250 \mathrm{mg}$ of dry extract were exactly weighed on an analytical balance (Ohaus Model PA 214), for triplicate and poured on vials bottles at $20^{\circ} \mathrm{C}$. The samples uncovered were placed in a moisture chamber of the sutured solution of sodium chloride $(72 \%$ RM) for $264 \mathrm{~h}$. The gain percentage in the environments was calculated by means of the change in the weight of the dry extract.

\section{Statistical analysis of the response variables}

The statistical evaluation of results derived from the SED was carried out using analysis of variance (ANOVA). The effect of each main factor, as well as its interactions between two factors were calculated with the estimated coefficient. If the sign of the estimated coefficient is positive $(+)$ indicates a direct and proportional effect of the factor on the evaluated response variable, but on the contrary if the sign of the coefficient is negative (-), it indicates an inverse proportionality of the factor on the variable. The statistical significance is established through the value of $\mathrm{p}$; values less than 0.05 indicate that the impact factor is significant with at least $95 \%$ confidence. Responses were related to the main effects and interactions of two factors by equation 3 .

$$
\gamma=h_{0}+\Sigma_{i} b_{i} X_{i}+\Sigma_{i} \Sigma_{i=i} h_{i j} X_{i} X_{j}
$$

(Equation 3)

Where $\gamma$ is the response variable or its mathematical transformation. The parameter $b_{0}$ is the intersection, calculated as the arithmetic mean of the response for all experiments; $b_{i}$ and $b_{i j}$ are coefficients of the main effects model and the interactions of two factors, respectively [32]. To overall effects, a positive coefficient indicates that the response increases as the level of the variable increases, while a negative coefficient shows that the response increases as the level of the variable decreases; $X_{i}$ represents the level of the factors to be studied. All statistical analyzes were performed in Minitab 17 software (license \# 1145461-127375 granted to the Universidad Nacional de Colombia).

\section{Evaluation of the dry extract}

From information derived of SED, SD conditions were chosen. Dry powder extract, was obtained by SD technique under these conditions and assays previously reported to the response variables, were carried out. Additional characterization was made by DSC, XRPD and evaluation of the antidiabetic activity through inhibition of $\alpha$-amylase in vitro assay.

\section{Thermal analysis}

Thermal behavior of the samples was evaluated by DSC in a Shimadzu DSC-60 equipment. This analysis was performed with the extract dried in oven, the drying coadjuvant, the physical mixture of the extract with the drying coadjuvant and the dry extract obtained by SD with the coadjuvant. Heating started at a temperature of about $25{ }^{\circ} \mathrm{C}$ and was brought up to $200{ }^{\circ} \mathrm{C}$ with a heating ramp of 10 ${ }^{\circ} \mathrm{C} / \mathrm{min}$. The samples were placed in an aluminum pan and sealed under a nitrogen atmosphere at a flow rate of $50 \mathrm{ml} / \mathrm{min}$. The results were analyzed using the TA Analysis Software.

\section{$\mathrm{X}$-ray powder diffraction}

Dry extract, drying coadjuvant and dry extract obtained by SD with the coadjuvant were characterized by XRPD analysis using a PANalytical X'Pert PRO MRD diffractometer, with an anodic X-ray tube PW3373/00 Cu LFF DK332001. The anodic X-ray tube was operated at $45 \mathrm{kV}$ and $40 \mathrm{~mA}$, the measurements were taken in a range of $0^{\circ}-100^{\circ}$ in the $2 \theta$ scale, with a sweep speed of $0.0263^{\circ} 2 \theta / \mathrm{s}$.

\section{Antidiabetic activity through inhibition of $\alpha$-amylase in vitro assay}

In order to determine the effect of SD on the inhibitory activity of the extract, an in vitro $\alpha$-amylase inhibition test was performed on dry extract by oven, dry extract obtained by SD with and without coadjuvant, physical mixture of the extract with the drying coadjuvant and coadjuvant alone, following the procedure based on the hydrolysis of starch covalently linked to Remazol Brilliant Blue [33], described by Hansawasdi-Kawabata [34] and modified by Rey et al. [4]. Briefly, $200 \mu \mathrm{l}$ of Blue Starch $(10 \mathrm{mg} / \mathrm{ml})$ were boiled for 5 min. Then, $100 \mu \mathrm{l}$ of Tris- $\mathrm{HCl}$ buffer $(0.05 \mathrm{M}, \mathrm{pH} 6.9$ with calcium chloride $0.01 \mathrm{M}), 100 \mu \mathrm{l}$ of alpha-amylase $(2.1 \mathrm{IU} / \mathrm{ml})$ and $200 \mu \mathrm{l}$ of extract of $P$. peruviana or acarbose as positive control were added. Absorbance at $595 \mathrm{~nm}$ was read after incubation for one hour at 37 ${ }^{\circ} \mathrm{C}$, using a TECAN GENIOS spectrophotometer. The results of in vitro inhibition of $\alpha$-amylase assays were expressed as the arithmetic mean of the valuestthe standard deviation. The data were analyzed using the Bomferroni test to show possible changes in the activity of the fruit extract of $P$. peruviana [35].

\section{RESULTS AND DISCUSSION}

Fluid extract was obtained, and the refractive index of each concentration was determined as mentioned in the methodology (Supplementary material).

\section{Preparation of the spray dried extract: SED}

The samples resulting of the SED were prepared and the viscosity of each sample was measured (Results no shown). The drying conditions of extract were established from analysis of each response variable, identifying the combination of factor levels that increase or decrease the response. In all cases analysis of variance was employed.

\section{Process yield}

The process yield for each run are showed in table 3 . The highest achieved yield was obtained in the experiment $8(68.81 \pm 1.03 \%)$, while the lowest one with the experiment $16(34.03 \pm 10.67 \%)$.

\begin{tabular}{|c|c|c|c|c|c|c|c|c|}
\hline Exp. & PY & MC & OT & PS & AR & AV & CI & HG \\
\hline 1 & $65.79 \pm 1.04$ & $1.94 \pm 0.27$ & $50 \pm 2.08$ & $2.35 \pm 0.13$ & $37.15 \pm 1.14$ & $6.52 \pm 0.25$ & $16.93 \pm 0.85$ & $13.73 \pm 0.20$ \\
\hline 2 & $61.45 \pm 2.16$ & $1.27 \pm 0.11$ & $79 \pm 1.15$ & $4.43 \pm 0.23$ & $39.56 \pm 0.56$ & $4.35 \pm 0.17$ & $17.81 \pm 0.65$ & $14.98 \pm 0.50$ \\
\hline 3 & $47.46 \pm 6.18$ & $1.50 \pm 0.04$ & $46 \pm 2.08$ & $3.95 \pm 0.21$ & $45.29 \pm 0.52$ & $9.01 \pm 0.19$ & $21.32 \pm 0.47$ & $8.84 \pm 0.40$ \\
\hline 4 & $59.89 \pm 6.07$ & $0.90 \pm 0.20$ & $50 \pm 2.52$ & $3.93 \pm 0.09$ & $45.78 \pm 0.48$ & $7.89 \pm 0.18$ & $18.56 \pm 0.87$ & $8.66 \pm 0.30$ \\
\hline 5 & $61.40 \pm 0.97$ & $0.68 \pm 0.27$ & $70 \pm 2.52$ & $3.05 \pm 0.18$ & $45.10 \pm 0.50$ & $5.91 \pm 0.24$ & $18.74 \pm 1.46$ & $13.88 \pm 0.58$ \\
\hline 6 & $54.43 \pm 4.25$ & $0.21 \pm 0.07$ & $72 \pm 2.52$ & $4.37 \pm 0.53$ & $43.22 \pm 3.47$ & $4.86 \pm 0.17$ & $17.00 \pm 1.71$ & $14.20 \pm 0.31$ \\
\hline 7 & $54.27 \pm 1.16$ & $0.77 \pm 0.14$ & $54 \pm 1.15$ & $5.79 \pm 0.88$ & $37.88 \pm 8.22$ & $5.88 \pm 0.16$ & $16.72 \pm 0.20$ & $9.74 \pm 0.10$ \\
\hline 8 & $68.81 \pm 1.03$ & $0.82 \pm 0.13$ & $79 \pm 2.08$ & $5.30 \pm 1.16$ & $46.43 \pm 0.85$ & $7.33 \pm 0.03$ & $16.87 \pm 0.28$ & $10.23 \pm 0.15$ \\
\hline 9 & $64.30 \pm 1.64$ & $0.14 \pm 0.05$ & $77 \pm 1.15$ & $4.54 \pm 0.16$ & $48.70 \pm 0.72$ & $4.94 \pm 0.04$ & $13.03 \pm 0.78$ & $15.11 \pm 1.72$ \\
\hline 10 & $66.52 \pm 3.46$ & $0.96 \pm 0.28$ & $46 \pm 2.65$ & $3.36 \pm 0.42$ & $47.31 \pm 1.54$ & $5.18 \pm 0.05$ & $16.77 \pm 0.49$ & $13.98 \pm 0.46$ \\
\hline 11 & $56.30 \pm 4.18$ & $1.65 \pm 0.13$ & $64 \pm 4.00$ & $3.76 \pm 1.24$ & $47.48 \pm 1.25$ & $9.01 \pm 0.25$ & $20.47 \pm 2.02$ & $9.37 \pm 0.29$ \\
\hline 12 & $67.23 \pm 3.73$ & $1.45 \pm 0.14$ & $44 \pm 3.46$ & $3.45 \pm 0.49$ & $47.79 \pm 0.29$ & $8.05 \pm 0.06$ & $18.22 \pm 1.88$ & $10.20 \pm 0.50$ \\
\hline 13 & $64.75 \pm 10.27$ & $1.11 \pm 0.21$ & $48 \pm 0.58$ & $3.50 \pm 0.39$ & $48.19 \pm 0.32$ & $5.01 \pm 0.16$ & $12.85 \pm 1.16$ & $13.00 \pm 0.60$ \\
\hline 14 & $61.77 \pm 0.45$ & $0.75 \pm 0.13$ & $74 \pm 3.79$ & $2.97 \pm 0.23$ & $47.53 \pm 1.48$ & $6.22 \pm 0.12$ & $21.54 \pm 0.54$ & $15.61 \pm 1.07$ \\
\hline 15 & $64.28 \pm 0.06$ & $1.14 \pm 0.04$ & $64 \pm 1.00$ & $3.95 \pm 0.24$ & $48.20 \pm 0.97$ & $8.23 \pm 0.19$ & $14.58 \pm 1.87$ & $9.38 \pm 0.46$ \\
\hline 16 & $34.03 \pm 10.67$ & $0.79 \pm 0.24$ & $52 \pm 0.58$ & $8.58 \pm 3.93$ & $42.90 \pm 6.16$ & $5.61 \pm 0.16$ & $13.21 \pm 0.64$ & $10.49 \pm 0.90$ \\
\hline
\end{tabular}

Table 3: Responses of the statistical experimental design

Exp. $=$ Experiment number; $\mathrm{PY}=$ Process Yield; $\mathrm{MC}=$ Moisture content; $\mathrm{OT}=$ Outlet temperature; $\mathrm{PS}=$ Particle size; $\mathrm{AR}=\mathrm{Angle}$ of repose; $\mathrm{AV}=$ apparent voluminosity; $\mathrm{CI}=$ Carr index; $\mathrm{HG}=$ Hygroscopicity. The values represent the mean \pm standard. 
According to the analysis of SED (table 4), a significant effect of the extract concentration (factor E) and the coadjuvant proportion (factor F) on the process yield was found, with a coefficient of0.4179 , $p$-value: 0.0001 and-0.4732, $p$-value: 0.00004 , respectively; thus, indicating that these variables in their higher value, affect negatively the process yield. These results could be explained because a higher content of solids in the extract and a higher dry coadjuvant ratio could increase the viscosity of the solution (supplementary material), allowing a rise in the concentration of the solids in the suspension, generating an increase of the mass dried that could be deposited on the walls of the chamber dry [36]. In the same way, Tonon et al. [36] found that the increase in the concentration of maltodextrin (drying adjuvant) in a range of 10 to $30 \%$, has a negative effect on the performance of the drying process by spraying the pulp of the açai fruit.

\section{Moisture content}

Extract powder showed a low moisture content, with a lower value of $0.14 \%$, run 9 and a higher value of $1.94 \%$, run 1 (table 3 ). This low value could be explained because the extract solvent is ethanol, affecting the water content of each dry extract obtained [23, 37]; the moisture content is important because it could affect the flowability properties, product compressibility, agglomerating tendency and product stability $[18,38]$. Considering the low level of humidity reached in the tests, to achieve a good performance in the afore mentioned characteristics, this value is intended to be as high as possible.

The statistical analyses showed a high effect of the factors A, B and D (Inlet temperature, atomization air flow rate and aspirator setting respectively), over the dry extract moisture content, with estimated coefficients of- $0.35,0.60$ and 0.39 (table 4). These results indicate that factor $A$ at its upper level disfavored the variable (-sign), while the factors B and D, at the same level, favor the variable (+sign).

The analysis of this behavior is widely detailed in the scientific literature $[18,23,25,37-40]$. These results agree with Souza et al. [18], in this research the evaporation capacity in SD process depends on the inlet temperature and feed rate (pump setting) and are determining factors in the moisture content of Bauhinia forficata extract. On the other hand, several authors have found that the inlet temperature at its upper level has a negative influence on the moisture content for different extracts [36, 39-43].

Table 4: Estimated coefficients of the model an $p$-values to the main factors and two-factor combinations

\begin{tabular}{|c|c|c|c|c|c|c|c|c|c|c|c|c|c|c|c|c|}
\hline \multirow{2}{*}{$\begin{array}{l}\text { Fact } \\
\text { or }\end{array}$} & \multicolumn{2}{|l|}{ PY } & \multicolumn{2}{|l|}{ MC } & \multicolumn{2}{|l|}{ OT } & \multicolumn{2}{|l|}{ PS } & \multicolumn{2}{|l|}{ AR } & \multicolumn{2}{|l|}{$\mathbf{A V}$} & \multicolumn{2}{|l|}{ CI } & \multicolumn{2}{|l|}{ HG } \\
\hline & $\begin{array}{l}\text { Est. } \\
\text { C. }\end{array}$ & $p$-value & $\begin{array}{l}\text { Est. } \\
\text { C. }\end{array}$ & $\begin{array}{l}p \text { - } \\
\text { value }\end{array}$ & Est. C. & $p$-value & $\begin{array}{l}\text { Est. } \\
\text { C. }\end{array}$ & $\begin{array}{l}p \text { - } \\
\text { value }\end{array}$ & $\begin{array}{l}\text { Est. } \\
\text { C. }\end{array}$ & p-value & Est. C. & $\begin{array}{l}p- \\
\text { value }\end{array}$ & $\begin{array}{l}\text { Est. } \\
\text { C. }\end{array}$ & $\begin{array}{l}p- \\
\text { value }\end{array}$ & $\begin{array}{l}\text { Est. } \\
\text { C. }\end{array}$ & $\begin{array}{l}p- \\
\text { value }\end{array}$ \\
\hline $\mathbf{A}$ & $\begin{array}{l}0.05 \\
09\end{array}$ & 0.59 & $\begin{array}{l}- \\
0.3 \\
5\end{array}$ & $\begin{array}{l}0.0007 \\
* * *\end{array}$ & $\begin{array}{l}11.166 \\
67\end{array}$ & $\begin{array}{l}2.00 \mathrm{E}- \\
16^{* * *}\end{array}$ & $\begin{array}{l}- \\
0.0 \\
46\end{array}$ & $\begin{array}{l}0.699 \\
01\end{array}$ & $\begin{array}{l}0.584 \\
5\end{array}$ & 0.7476 & $\begin{array}{l}4.0905 \\
2\end{array}$ & $\begin{array}{l}0.042 \\
954^{*}\end{array}$ & $\begin{array}{l}0.08 \\
8\end{array}$ & 0.48 & 0.06 & $\begin{array}{l}0.0027 \\
* *\end{array}$ \\
\hline B & $\begin{array}{l}0.14 \\
10\end{array}$ & 0.12 & $\begin{array}{l}0.6 \\
0\end{array}$ & $\begin{array}{l}0.0000 \\
* * *\end{array}$ & -3.75 & $\begin{array}{l}5.46 \mathrm{E}- \\
09^{* * *}\end{array}$ & $\begin{array}{l}- \\
0.6 \\
23\end{array}$ & $\begin{array}{l}5.46 \mathrm{E}- \\
09^{* * *}\end{array}$ & $\begin{array}{l}2.169 \\
4\end{array}$ & 0.338 & $\begin{array}{l}1.7634 \\
1\end{array}$ & $\begin{array}{l}0.103 \\
551\end{array}$ & $\begin{array}{l}0.08 \\
2\end{array}$ & 0.50 & -0.01 & 0.3377 \\
\hline C & $\begin{array}{l}0.05 \\
33\end{array}$ & 0.55 & $\begin{array}{l}- \\
0.1 \\
9\end{array}$ & 0.067 & $\begin{array}{l}- \\
1.1666 \\
7\end{array}$ & $\begin{array}{l}0.01989 \\
*\end{array}$ & $\begin{array}{l}- \\
0.1 \\
75\end{array}$ & $\begin{array}{l}0.146 \\
78\end{array}$ & $\begin{array}{l}8.797 \\
8\end{array}$ & $\begin{array}{l}0.01292 \\
*\end{array}$ & $\begin{array}{l}3.9186 \\
3\end{array}$ & $\begin{array}{l}0.022 \\
202^{*}\end{array}$ & $\begin{array}{l}- \\
0.92 \\
07\end{array}$ & $\begin{array}{l}0.000^{*} \\
* *\end{array}$ & 0.03 & 0.055 \\
\hline D & $\begin{array}{l}0.09 \\
9\end{array}$ & 0.29 & $\begin{array}{l}0.3 \\
9\end{array}$ & $\begin{array}{l}0.0002 \\
* * *\end{array}$ & $\begin{array}{l}1.6666 \\
7\end{array}$ & $\begin{array}{l}0.00138 \\
7^{* *}\end{array}$ & $\begin{array}{l}0.0 \\
62\end{array}$ & $\begin{array}{l}0.600 \\
90\end{array}$ & $\begin{array}{l}0.321 \\
1\end{array}$ & 0.8517 & $\begin{array}{l}- \\
0.9937 \\
8\end{array}$ & $\begin{array}{l}0.231 \\
707\end{array}$ & $\begin{array}{l}- \\
0.14 \\
147\end{array}$ & 0.28 & 0.04 & $0.021^{*}$ \\
\hline $\mathbf{E}$ & $\begin{array}{l}- \\
0.41 \\
79\end{array}$ & $\begin{array}{l}0.0001^{*} \\
* *\end{array}$ & $\begin{array}{l}- \\
0.0 \\
3\end{array}$ & 0.7806 & $\begin{array}{l}0.6666 \\
7\end{array}$ & $\begin{array}{l}0.42469 \\
5\end{array}$ & $\begin{array}{l}- \\
0.0 \\
53\end{array}$ & $\begin{array}{l}0.793 \\
87\end{array}$ & $\begin{array}{l}- \\
17.28 \\
99\end{array}$ & $\begin{array}{l}0.00017 \\
6^{* * *}\end{array}$ & $\begin{array}{l}- \\
2.8340 \\
1\end{array}$ & $\begin{array}{l}0.000 \\
169^{* *} \\
*\end{array}$ & $\begin{array}{l}- \\
0.07 \\
72\end{array}$ & 0.60 & 0.04 & $0.003^{*}$ \\
\hline $\mathbf{F}$ & $\begin{array}{l}- \\
0.47 \\
32\end{array}$ & $\begin{array}{l}0.0000 \\
4^{* * *}\end{array}$ & $\begin{array}{l}0.1 \\
78\end{array}$ & 0.2199 & -2.75 & $\begin{array}{l}0.05239 \\
8\end{array}$ & $\begin{array}{l}- \\
0.2 \\
47\end{array}$ & $\begin{array}{l}0.455 \\
43\end{array}$ & $\begin{array}{l}2.451 \\
9\end{array}$ & 0.2935 & $\begin{array}{l}10.619 \\
39\end{array}$ & $\begin{array}{l}3.08 \mathrm{E}- \\
06^{* * *}\end{array}$ & $\begin{array}{l}- \\
0.30 \\
05\end{array}$ & $0.04^{*}$ & -0.42 & $\begin{array}{l}0.0000 \\
* * *\end{array}$ \\
\hline A: $B$ & - & - & - & - & $\begin{array}{l}- \\
0.5833 \\
3\end{array}$ & 0.22932 & $\begin{array}{l}0.0 \\
33\end{array}$ & $\begin{array}{l}0.782 \\
12\end{array}$ & - & - & $\begin{array}{l}- \\
3.3394 \\
6\end{array}$ & $\begin{array}{l}0.001 \\
223^{* *}\end{array}$ & - & - & - & - \\
\hline A: $C$ & - & - & - & - & $\begin{array}{l}1.3333 \\
3\end{array}$ & $\begin{array}{l}0.00856 \\
7^{* *}\end{array}$ & $\begin{array}{l}- \\
0.0 \\
49\end{array}$ & $\begin{array}{l}0.669 \\
11\end{array}$ & - & - & $\begin{array}{l}0.0877 \\
5\end{array}$ & $\begin{array}{l}0.926 \\
308\end{array}$ & - & - & - & - \\
\hline A: D & - & - & - & - & 0.25 & $\begin{array}{l}0.60304 \\
7\end{array}$ & $\begin{array}{l}0.1 \\
55\end{array}$ & $\begin{array}{l}0.184 \\
09\end{array}$ & - & - & $\begin{array}{l}5.8083 \\
9\end{array}$ & $\begin{array}{l}6.63 \mathrm{E}- \\
07^{* * *}\end{array}$ & - & - & - & - \\
\hline A: $E$ & - & - & - & - & $\begin{array}{l}0.0833 \\
3\end{array}$ & $\begin{array}{l}0.92011 \\
8\end{array}$ & $\begin{array}{l}- \\
0.4 \\
66\end{array}$ & $\begin{array}{l}0.030 \\
01^{*}\end{array}$ & - & - & $\begin{array}{l}2.8017 \\
8\end{array}$ & $\begin{array}{l}0.095 \\
36\end{array}$ & - & - & - & - \\
\hline A: $F$ & - & - & - & - & $\begin{array}{l}1.9166 \\
7\end{array}$ & $\begin{array}{l}0.16422 \\
2\end{array}$ & $\begin{array}{l}- \\
0.3 \\
41\end{array}$ & $\begin{array}{l}0.305 \\
11\end{array}$ & - & - & $\begin{array}{l}- \\
9.1614 \\
5\end{array}$ & $\begin{array}{l}0.001 \\
632^{* *}\end{array}$ & - & - & - & - \\
\hline B: $C$ & - & - & - & - & $\begin{array}{l}0.8333 \\
3\end{array}$ & $\begin{array}{l}0.08957 \\
1\end{array}$ & $\begin{array}{l}- \\
0.0 \\
95\end{array}$ & $\begin{array}{l}0.422 \\
13\end{array}$ & - & - & $\begin{array}{l}- \\
2.3317 \\
8\end{array}$ & $\begin{array}{l}0.018 \\
708^{* *}\end{array}$ & - & - & - & - \\
\hline B: D & - & - & - & - & $\begin{array}{l}- \\
0.9166 \\
7\end{array}$ & 0.06305 & $\begin{array}{l}- \\
0.1 \\
59\end{array}$ & $\begin{array}{l}0.184 \\
45\end{array}$ & - & - & $\begin{array}{l}2.7425 \\
7\end{array}$ & $\begin{array}{l}0.006 \\
466^{* *}\end{array}$ & - & - & - & - \\
\hline B: $\mathbf{E}$ & - & - & - & - & -0.75 & $\begin{array}{l}0.36977 \\
3\end{array}$ & $\begin{array}{l}- \\
0.2 \\
29\end{array}$ & $\begin{array}{l}0.260 \\
42\end{array}$ & - & - & $\begin{array}{l}7.3207 \\
8\end{array}$ & $\begin{array}{l}8.68 \mathrm{E}- \\
05^{* * *}\end{array}$ & - & - & - & - \\
\hline C: D & - & - & - & - & 3 & $\begin{array}{l}0.00095 \\
4^{* * *}\end{array}$ & $\begin{array}{l}0.1 \\
25\end{array}$ & $\begin{array}{l}0.531 \\
83\end{array}$ & - & - & $\begin{array}{l}- \\
6.4343 \\
3\end{array}$ & $\begin{array}{l}0.000 \\
407^{* *} \\
*\end{array}$ & - & - & - & - \\
\hline
\end{tabular}

$\mathrm{PY}=$ Process Yield; $\mathrm{MC}=$ Moisture content; OT = Outlet temperature; $\mathrm{PS}=$ Particle size; $\mathrm{AR}=$ Angle of repose; $\mathrm{AV}=$ apparent voluminosity; $\mathrm{CI}=\mathrm{Carr}$ index; HG = Hygroscopicity. ${ }^{*} \mathrm{P}<0.05 ;{ }^{* *} \mathrm{p}<0.01 ;{ }^{* * *} \mathrm{p}<0.001$

\section{Physical-mechanic properties}

\section{Particle morphology and size distribution}

According with the results, summarized in the table 3, the lower value to the particle size was $2.36 \mu \mathrm{m}$ and the higher value was 8.58 $\mu \mathrm{m}$ corresponding to the experiment 1 and 16 , respectively, as is showed in the fig. 1.

All samples studied showed a unimodal behavior and the shape of particles was spherical. Ethanol used in the drying process, contributes to obtain smaller particle sizes, due to the low 
surface tension of this solvent $\left(22.75 \mathrm{mN} / \mathrm{m}\right.$ at $20{ }^{\circ} \mathrm{C}$; ethanol/ vapor) $[37,44]$.

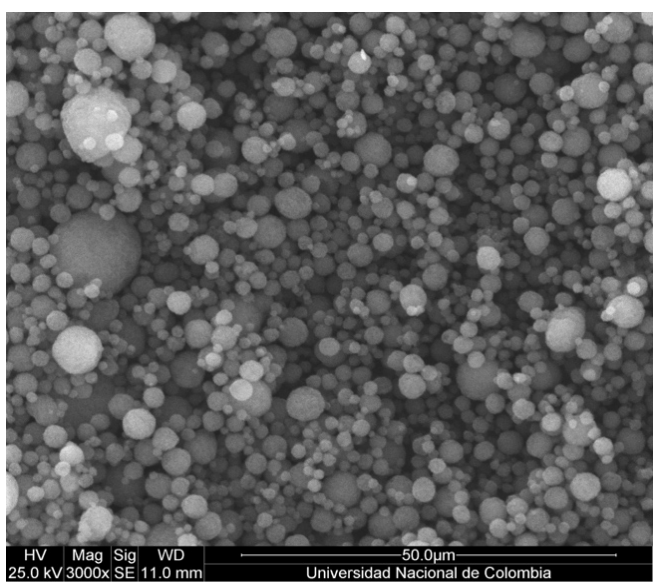

A

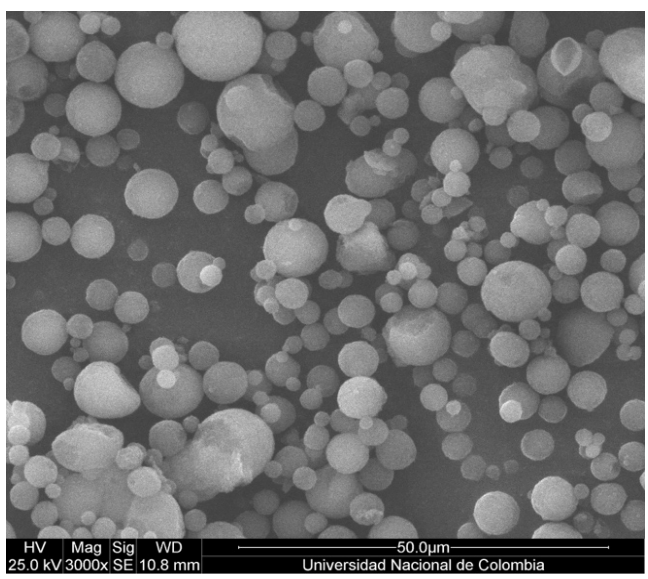

B

Fig. 1: SEM microphotographs of spray dried P. peruviana fruit extract, A) sample 1, 3000x; B) sample 16, 3000x

In table 4 the estimated coefficients for the particle size and their respective $p$-values, with a significance level of 0.05 were presented. According to these results only the flow rate of the injection nitrogen (Factor B) influenced the particle size with a $p$-value of 5.46E-09 and a coefficient of-0.623, indicating that a decrease in the flow rate of the atomizing nitrogen produce larger droplets in the atomizing nozzle, allowing the formation of larger particles [23, 24, 36, 37]. Atomization is a decisive step in the spray drying process since the initial conditions of the spray define the initial distribution of droplet sizes and it can affect the characteristics of the particles produced. In general, an increase in the energy available for atomization (ie, atomizer speed, nozzle pressure, or nitrogen-liquid ratio in a pneumatic atomizer) will result in a particle size reduction $[23,24]$.

In the same way, a negative effect on the response variable (particle size) is evidenced due to a combination of injection temperature and extract concentration (A and E); it was expected because at high concentration in the extract, solids in each drop would increase and therefore, a larger particle size would be obtained. However, due to an increase in temperature, the response variable produces samples with smaller particle size, possibly due to the evaporation of ethanol before they are formed from larger droplets. Some authors [25, 36, 39] found similar results.

\section{Angle of repose}

According to the results of the statistical analysis, factors $\mathrm{C}$ and $\mathrm{E}$ (pump setting and extract concentration) showed a significant effect on the angular response of flow capacity (table 4), where the angle of repose decreases (improves the fluidity of the material) with a decrease of $\mathrm{C}$ and an increase in factor $\mathrm{E}$.

In addition, it can be inferred that increasing the feed rate (Factor $\mathrm{C}$ ) increases the liquid to evaporate during the process, which generates a greater moisture content resulting in the solid obtained after drying. Higher moisture content improves the flow properties of the material [23,37]. On the other hand, a higher concentration of extract (Factor E) means less liquid to evaporate in the drying and therefore more solids in a drop which produces an increase in particle size and a final product with a more fluid flow of powder $[30,31,42,45,46]$. The effect of total solids content on flowability is in accordance with the results reported by Moreira et al. [42] and Gallo et al. [27].

\section{Bulk and tap densities}

The bulk and tap densities were evaluated, but only the voluminosity and the index Carr where assessed to the SED.

The lower response of the bulk voluminosity was $4.35 \mathrm{ml} / \mathrm{g}$ and the higher was $9.01 \mathrm{ml} / \mathrm{g}$, in runs 2 and 11 , respectively (table 3 ). According to the statistical analysis, it is evident that the voluminosity decreases with the factors A-, C-, E+and F-, (Injection temperature, pump settings, extract concentration and coadjuvant proportion) (table 4).

A lower injection temperature (factor A) provides a product with a higher moisture content, favoring the cohesive forces of the particles, allowing to form agglomerates which will tend to behave as larger particles, thus reducing the voluminosity of the solid [31, 37, 46]. A lower pump setting (factor C) decreases the size of the liquid droplets, since less liquid must be dispersed, therefore, smaller particles could be obtained, resulting in a decrease in the voluminosity; when the particle sizes are too small the voluminosity may increase, because charges can be generated repelling the particles forming large spaces (electrostatic forces) [46]. A higher concentration of extract (factor E) results in a greater amount of solids in a drop with increases in particle size, which could favor the decrease of the voluminosity [23,37]. Use of colloidal silicon dioxide as a coadjuvant of dry, in a high proportion (factor F), could adversely affect the voluminosity of the particles causing an increase in the electrostatic forces which consequently increase of the voluminosity of the particles [23, 25, 36, 37].

According to the statistical analysis of the interactions of the factors of injection temperature and drying adjuvant ratio (A: F), it is suggested that the bulkiness is lower when they are at the lowest level, which agrees with the explanations previously analyzed. Jangam and Thorat [43], found similar results in the ginger extract SD process, where they obtained more compact (less bulky) materials with a low injection temperature, low feed speed (low pump setting) and high atomization pressure.

On the other hand, Carr Index (CI), shows the relationship between the properties of cohesion of the solids with their flowability, being an indicator of the compressibility of the material $[31,46]$, therefore, it was sought that this index was as small as possible. According to table 3 , the lowest and highest CI values were $12.85 \%$ and $21.54 \%$, from experiments 15 and 14, respectively, which correspond to materials with good and acceptable flow according to with this classification [30,46]. The statistical analysis also shows pump setting (Factor $\mathrm{C}$ ) and coadjutant proportion (Factor F) as significant estimated coefficients of- 0.9207 and- 0.3005 , respectively (table 4), which means that to reduce the $\mathrm{CI}$, it is required that the factors that affect this variable are at their highest values.

Similarly, to the flow properties (angle of repose), according to the statistical analysis a greater pump setting (Factor C) implies a higher feed rate that results in an increase of the concentration of solids in a drop and in the particle size, which could favor IC values, which contributes to a better flow and packing of the powders. The same behavior was observed with a higher extract concentration [39]. Gallo et al. found a similar behavior for the IC, where the factor with the greatest effect was the solids concentration, for which a higher concentration of solids allowed a decrease in the IC [25]. 


\section{Hygroscopicity}

Due to the high hygroscopicity of the dry extract [3], the obtained dry product must reach a low hygroscopicity. The results here presented shows that injection temperature, aspirator settings, extract concentration and coadjuvant proportion (factors A, D, E, and $\mathrm{F}$, respectively) were significant to the hygroscopicity, which decreases whit combinations of the factors A-, D-, E-and F+(table 4).

The hygroscopicity showed values between $8.84 \%$ and $15.61 \%$. Experiments 3, 4, 7, 8, 11, 12, 15 and 16 were the particles with the higher proportion of colloidal silicon dioxide that showed the lowest hygroscopicity and this was the factor with the main influence in this variable (Factor F) (table 3). For high concentrations of colloidal silicon dioxide, the extract could be trapped within these solid particles and then it could be almost unavailable for water adsorption [44].
On the other hand, when a lower inlet temperature (Factor A-) and a higher aspirator rate (Factor D+) were applied, solids with a major moisture content were obtained, contributing in this way to improve the performance of the powder against moisture because of the lower rate of water incorporation under these conditions [47].

Gallo et al. reported the same behavior where a high concentration of silicon dioxide favors the decrease of hygroscopicity [25]; in the same way, Tonon et al. found that lower hygroscopicity values were obtained with the highest values of maltodextrin concentration [36].

\section{Evaluation of the dry extract}

The resulting statistical analysis that leads to define the most appropriate conditions (operational variables or factors) for the drying process of $P$. peruviana fruit extract are summarized in table 5 .

Table 5: Drying process summary

\begin{tabular}{|c|c|c|c|c|c|c|c|}
\hline Variable & Desired effect & Factor A & Factor B & Factor C & Factor D & Factor $\mathbf{E}$ & Factor $\mathbf{F}$ \\
\hline Process yield & 个 & No & No & No & No & - & - \\
\hline Moisture content & $\uparrow$ & - & + & No & + & No & No \\
\hline Outlet temperature & $\uparrow$ & + & - & - & + & No & - \\
\hline Particle size & $\uparrow$ & No & - & No & No & No & No \\
\hline Voluminosity & $\downarrow$ & - & No & - & No & + & - \\
\hline Angle of response & $\downarrow$ & No & No & - & No & + & No \\
\hline Carr's index & $\uparrow$ & No & - & No & No & No & + \\
\hline Hygroscopicity & $\downarrow$ & - & No & No & - & - & + \\
\hline
\end{tabular}

$\uparrow:$ Variable increase; $\boldsymbol{\Downarrow}$ : Variable decrease; No: The factor has not statistically significant effect over the variable; +: The factor has statistically significant effect increasing the variable in their higher value; -: The factor has statistically significant effect decreasing the variable in their higher value.

It is noteworthy that although there were effects derived from some interactions between factors because they were not always possible to evaluate for all variables by the statistical procedures performed, the evaluation of the factors without considering the interactions were made.

Table 6 summarizes the levels selected for each of the factors evaluated in the SED. The selection of factor levels was based on the SED results, where, if the factor had a statistically significant effect at its higher value favoring most of the variables according to the desired result, then the upper level of the factor is selected. On the other hand, if the factor had a statistically significant effect at its lower value favoring most of the variables, then the lower level of the factor was selected. For the cases of factor E (extract concentration) and factor $\mathrm{F}$ (coadjuvant proportion), which had statistically significant effects both at their lower value and at their upper value, it was decided to take an intermediate value of the factor (table 6).

Table 6: Variables selected from the statistical experimental design

\begin{tabular}{|c|c|c|c|c|}
\hline Factor & Lower value (-) & Highest value (+) & Level selected & Units \\
\hline (A) Injection temperature & 80 & 120 & 80 & ${ }^{\circ} \mathrm{C}$ \\
\hline (B) Atomization air flow rate & 400 & 600 & 400 & $\mathrm{l} / \mathrm{h}$ \\
\hline (C) Pump setting & 5 & 15 & 5 & $\%$ \\
\hline (D) Aspirator setting & 80 & 100 & 100 & $\%$ \\
\hline (E) Extract concentration & 5.00 & 10.00 & 7.50 & $\%(\mathrm{p} / \mathrm{p})$ \\
\hline (F) Coadjuvant proportion & $1: 0,5$ & $1: 1$ & $1: 0.75$ & - \\
\hline
\end{tabular}

With the selected factors levels, an additional experiment was carried out, in which the same response variables of the SED were evaluated. The resulting mean values are shown in table 7 . Comparison with the minimum and maximum values obtained from the SED shows that DEE make possible to optimize the SD conditions of the extract and the most adequate proportion of colloidal silicon dioxide to produce co-processed material with an appropriate yield, moisture, particle size, bulkiness, fluidity and hygroscopicity.

Table 7: Results of the final experiment

\begin{tabular}{lllll}
\hline Variable & Desire effect & Minimum value & Maximum value & Value obtained \\
\hline Process yield & $\uparrow$ & $34.03 \%$ & $68.81 \%$ & $68.12 \%$ \\
Moisture content & $\uparrow$ & $0.211 \%$ & $1.939 \%$ & $1.547 \%$ \\
Outlet temperature & $\uparrow$ & $44{ }^{\circ} \mathrm{C}$ & $79{ }^{\circ} \mathrm{C}$ & $74^{\circ} \mathrm{C}$ \\
Particle size & $\uparrow$ & $2.36 \mu \mathrm{m}$ & $8.58 \mu \mathrm{m}$ & $4.18 \mu \mathrm{m}$ \\
Voluminosity & $\downarrow$ & $4.94 \mathrm{ml} / \mathrm{g}$ & $9.01 \mathrm{ml} / \mathrm{g}$ & $7.46 \mathrm{ml} / \mathrm{g}$ \\
Angle of response & $\Downarrow$ & $37.15^{\circ}$ & $48.700^{\circ}$ & $36.67^{\circ}$ \\
Carr's index & $\uparrow$ & $12.85 \%$ & $21.54 \%$ & $18.75 \%$ \\
Hygroscopicity & $\downarrow$ & $8.84 \%$ & $15.61 \%$ & $10.58 \%$ \\
\hline
\end{tabular}

$\uparrow:$ Increase in the variable; $\downarrow$ : Decrease in the variable, final characterization was made to dry extract obtained in the selected conditions. These results are shown below. 


\section{Thermal analysis}

According to results of the thermograms (fig. 2), it can be observed that the dry extract without coadjutant at temperatures above 120 ${ }^{\circ} \mathrm{C}$ begins a decomposition process, in agreement with the results obtained in previous works where it was found that the extract is thermolabile [3]; this decomposition is not evident in the extract coprocessed nor in the physical mixture, probably by the addition of colloidal silicon dioxide as drying coadjuvant, which could exert a protective effect by coating the extract, given its capacity to form hydrogen bonds and its high surface area [44]. On the other hand, there is a loss of water in the extract approximately at $40{ }^{\circ} \mathrm{C}$. This temperature moves $60^{\circ} \mathrm{C}$ in the co-processed material and $70{ }^{\circ} \mathrm{C}$ in the physical mixture, possibly due to the capacity of colloidal silicon dioxide of adsorbing water, which could require a higher temperature to be able to remove them [44].

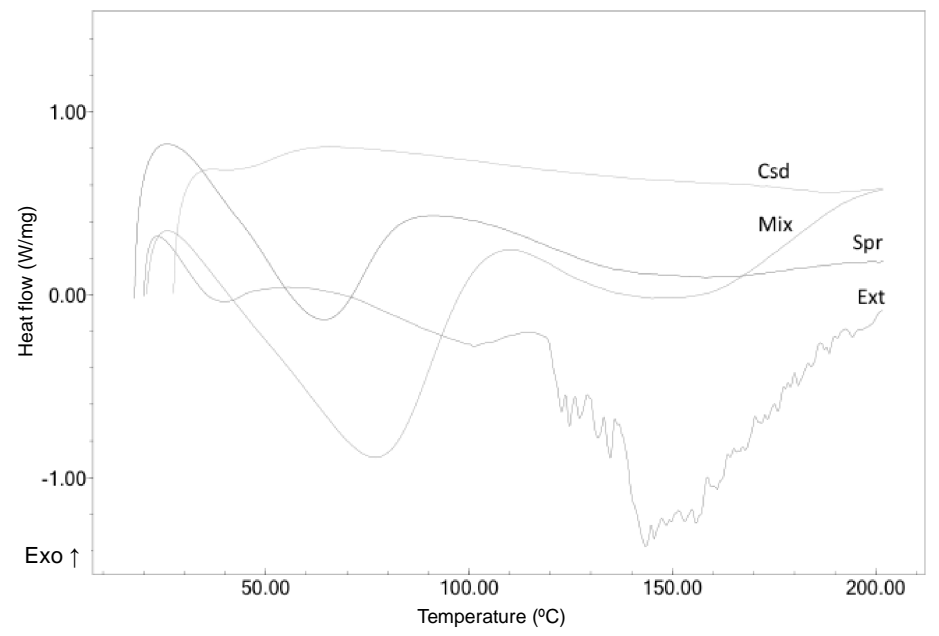

Fig. 2: DSC thermograms, Ext= Spray dried extract without colloidal silicon dioxide; Spr= Spray dried extract with colloidal silicon dioxide; Mix: Physical mixture; Csd= Colloidal silicon dioxide

\section{X-ray powder diffraction}

XRPD diffraction measurements were made for the dry extract with and without coadjuvant and the colloidal silicon dioxide.
All the samples evaluated revealed an amorphous state, characterized by the presence of broad undefined signals with abundant noise (fig. 3) [48].
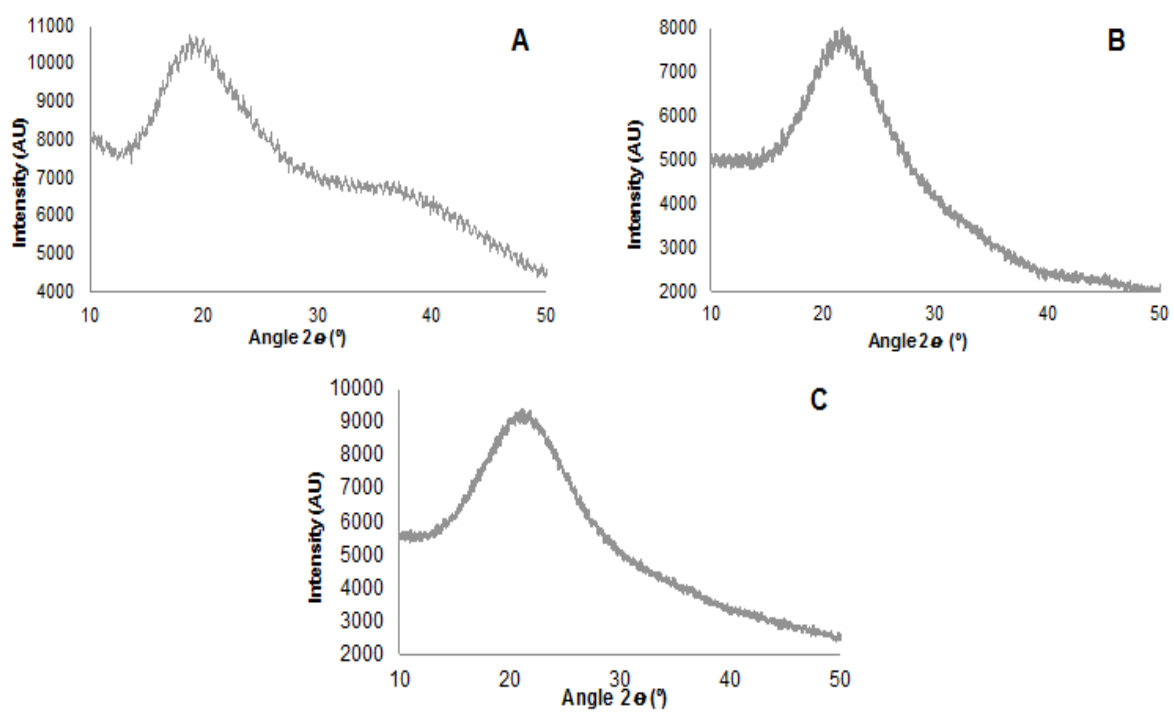

Fig. 3: XRPD diffractograms, A: Spray dried extract without colloidal silicon dioxide; B: Colloidal silicon dioxide; C: Spray dried extract with colloidal silicon dioxide

\section{Antidiabetic activity through inhibition of $\alpha$-amylase in vitro assay}

The results for the in vitro hypoglycemic assay are presented in fig. 4 , where the inhibitory effect of the extract was compared with acarbose used here as a control. According to these results, the colloidal silicon dioxide had not interfered with the assay. Also, can be seen how the extract dried in oven shows a decrease in the inhibitory activity due a degradation of the extract during the drying process [3]. On the other hand, neither the extract nor the extract formulated with colloidal silicon dioxide show statistically significant differences in the inhibitory effect on the alfa amylase. For that reason, the spray dried is adequate as the drying process for an ethanolic extract of fruits from Physalis peruviana $L$. 


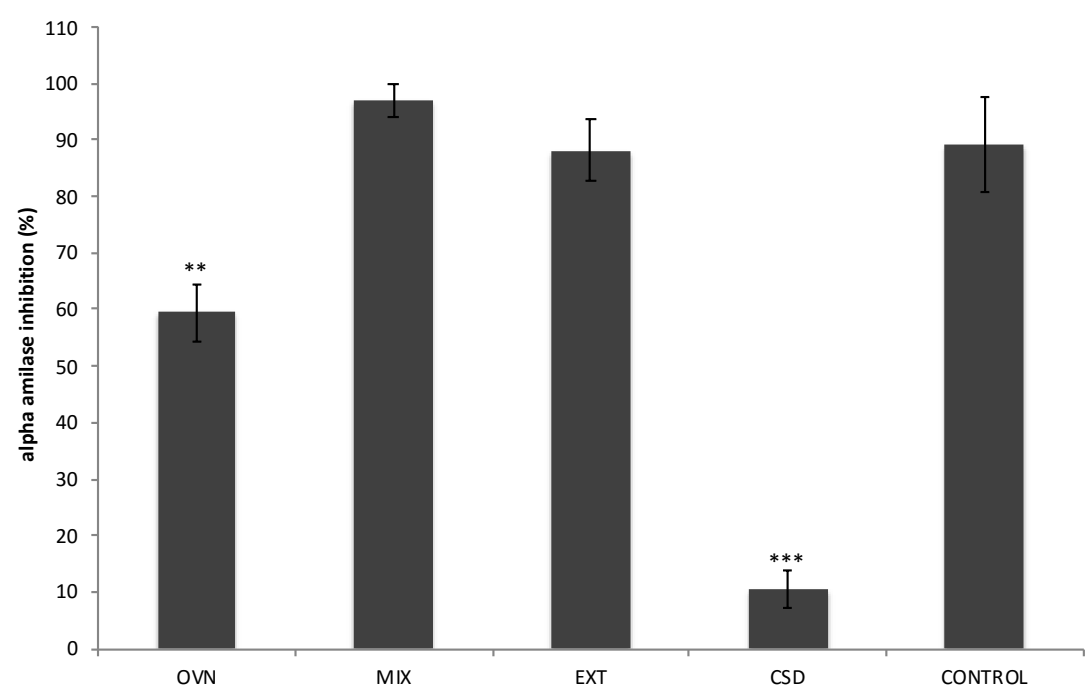

Fig. 4: Antidiabetic activity through inhibition of $\alpha$-amylase in vitro assay, average \pm SD; $n=3$ per group; ${ }^{* *} \mathbf{p}<0.01,{ }^{* * *} \mathbf{p}<0.001$ bonferroni test, $\mathrm{OVN}=$ extract dried in oven; MIX= spray dried extract with colloidal silicon dioxide; EXT = spray dried extract without colloidal silicon dioxide; CSD= colloidal silicon dioxide; $\operatorname{CONTROL}=$ Acarbose

\section{CONCLUSION}

The SED allowed to establish the conditions of SD, to obtain powder extract, from the ethanolic extract of the fruits of P. peruviana. Dry extract obtained under the selected conditions, showed an amorphous state by XRPD, a probable protective effect of colloidal silicon dioxide on the extract, characterized by DSC and an inhibitory activity of alfa amylase evaluated by in vitro studies. These studies allow to conclude that coprocessed material could be used to produce a compressed solid pharmaceutical form or employed as an intermediate herbal product from the ethanol extract of fruits of $P$. peruviana, for treatment of diabetes.

\section{ACKNOWLEDGMENT}

The authors acknowledge the Research Division of Universidad Nacional de Colombia for the scholarship of C. A. Bernal (DIB; grant 15192)

\section{AUTHORS CONTRIBUTIONS}

All the author have contributed equally

\section{CONFLICT OF INTERESTS}

\section{Declared none}

\section{REFERENCES}

1. Correa J, Bernal H. Especies vegetables promisorias de los países del convenio Andres Bello. Vol. VII. Santafe de Bogota, Colombia; 1992.

2. Garcia H. Flora medicinal de colombia botánica medica. Vol. 1. Bogota, Colombia: Instituto de Ciencias Naturales, Universidad Nacional de Colombia; 1974.

3. Bernal CA, Aragón M, Baena Y. Dry powder formulation from fruits of Physalis peruviana L. standardized extract with hypoglycemic activity. Powder Technol 2016;301:839-47.

4. Rey DP, Ospina LF, Aragon DM. Inhibitory effects of an extract of fruits of Physalis peruviana on some intestinal carbohydrases. Rev Colomb Ciencias Quimico Farm 2015; 44:72-89.

5. Sathyadevi M, Subramanian SP. Physalis peruviana L. fruits avert oxidative stress in pancreatic and hepatic tissues of streptozotocin-induced diabetic rats. Der Pharm Lett 2015;7:59-73.

6. Sorimuthu S, Sathyadevi M. Extraction, isolation and characterization of bioactive flavonoids from the fruits of Physalis peruviana linn extract. Asian J Pharm Clin Res 2015;8:152-7.
7. Franco LA, Ocampo YC, Gomez HA, De la Puerta R, Espartero JL, Ospina LF. Sucrose esters from Physalis peruviana calyces with anti-inflammatory activity. Planta Med 2014;80:1605-14.

8. Toro RM, Aragón DM, Ospina LF, Ramos FA, Castellanos L. Phytochemical analysis, antioxidant and anti-inflammatory activity of calyces from Physalis peruviana. Nat Prod Commun 2014;9:1573-5.

9. Neogi P, Sahai M, Ray AB. Withaperuvins F and G, two withanolides of Physalis peruviana roots. Phytochemistry 1986;26:243-7.

10. Morton JF. Fruits of warm climates. Miami, Florida: Creative Resorces Systems Inc; 1987.

11. Ospina LF, Pinzon R. Plantas usadas como antidiabéticas en la medicina popular colombiana. Rev Colomb Ciencias Quimico Farm 1995;23:81-94.

12. Wu SJ, Tsai JY, Chang SP, Lin DL, Wang SS, Huang SN. Antioxidant activities of Physalis peruviana. Biol Pharm Bull 2005;28:963-6.

13. Ahmad S, Malik A, Yasmin R, Ullah N, Gul W, Khan Pir, et al. Withanolides from Physalis peruviana. Phytochemistry 1999;50:647-51.

14. Bernal CA, Castellanos L, Aragon DM, Martínez-Matamoros D, Jimenez C, Baena Y, et al. Peruvioses A to F, sucrose esters from the exudate of Physalis peruviana fruit as $\alpha$-amylase inhibitors. Carbohydr Res 2018;461:4-10.

15. Gopi G, Kannan K. Formulation development and optimization of nateglinide-loaded ethyl cellulose nanoparticles by boxbehnken design. Int J Pharm Pharm Sci 2015;7:310-5.

16. Calixto JB. Efficacy, safety, quality control, marketing and regulatory guidelines for herbal medicines (phytotherapeutic agents). Brazilian J Med Biol Res 2000;33:179-89.

17. Mustarichie R, Priambodo D. Tablet formulation from meniran (Phyllanthus niruri L.) extract with a direct compression method. Int J Appl Pharm 2018;10:98-102.

18. Souza CRF, Oliveira WP. Powder properties and system behavior during spray drying of Bauhinia forficata link extract. Dry Technol 2006;24:735-49.

19. Patel H, Gohel M. A review on development of multifunctional co-processed excipient. J Crit Rev 2016;3:48-54.

20. Re MI. Formulating drug delivery systems by spray drying. Dry Technol 2006;24:433-46.

21. Maa YF, Costantino HR, Nguyen PA, Hsu CC. The effect of operating and formulation variables on the morphology of spray-dried protein particles. Pharm Dev Technol 1997; $2: 213-23$.

22. Wang S, Langrish T. A review of process simulations and the use of additives in spray drying. Food Res Int 2009;42:13-25. 
23. Cal K, Sollohub K. Spray drying technique. I: Hardware and process parameters. J Pharm Sci 2010;99:575-86.

24. Sollohub K, Cal K. Spray drying technique: II. Current applications in pharmaceutical technology. J Pharm Sci 2010;99:587-97.

25. Gallo L, Llabot JM, Allemandi D, Bucala V, Pina J. Influence of spray-drying operating conditions on Rhamnus purshiana (Cáscara sagrada) extract powder physical properties. Powder Technol 2011;208:205-14.

26. Gallo L, Ramirez-Rigo MV, Pina J, Palma S, Allemandi D, Bucala V. Valeriana officinalis dry plant extract for direct compression: preparation and characterization. Sci Pharm 2012;80:1013-26.

27. Gallo L, Pina J, Bucala V, Allemandi DA, Ramirez Rigo MV. Development of a modified-release hydrophilic matrix system of a plant extract based on co-spray-dried powders. Powder Technol 2013;241:252-62.

28. Palma SD, Manzo RH, Allemandi DA. Dry plant extracts loaded on fumed silica for direct compression: preparation and preformulation. Pharm Dev Technol 1999;4:523-30.

29. Adriany R, Anwar E, Andrajati R, Hanafi M. Formulation of an orodispersible tablet of Luffa acutangula (L) roxb using novel co-processed via spray dried excipient. Int J Pharm Pharm Sci 2015;7:124-9.

30. United States Pharmacopeia and National Formulary, USP 40NF 35. Rockville, MD: The United States Pharmacopeial Convention; 2017.

31. Martin AN, Sinko PJ, Singh Y. Martin's physical pharmacy and pharmaceutical sciences. Physical-chemical and biopharmaceutical principles in the pharmaceutical sciences, 6th ed. Baltimore, MD: Lippincott Williams and Wilkins; 2011.

32. Montgomery DC, Pina R, Zetina G. Diseno y análisis de experimentos. 2a. Mexico: Limusa Wiley; 2010.

33. Rinderknecht $\mathrm{H}$, Wilding $\mathrm{P}$, Haverback BJ. A new method for the determination of alpha-amylase. Experientia 1967;23:805.

34. Hansawasdi C, Kawabata J, Kasai T. $\alpha$-amylase inhibitor from roselle (Hibiscus sabdariffa Linn.) tea. Biosci Biotechnol Biochem 2000;64:1041-3.

35. Banerjee A, Maji B, Mukherjee $\mathrm{S}$, Chaudhuri $\mathrm{K}$, Seal T. In vitro anti-diabetic and antioxidant activities of ethanol extract of Tinospora sinensis. Int J Curr Pharm 2017; 9:42-7.

36. Tonon RV, Brabet $\mathrm{C}$, Hubinger MD. Influence of process conditions on the physicochemical properties of açai (Euterpe oleraceae Mart.) powder produced by spray drying. J Food Eng 2008;88:411-8
37. Buchi. Mini Spray Dryer B-290; 2017. Available from: http://www.buchi.com/en/products/spray-drying-andencapsulation/mini-spray-dryer-b-290. [Last accessed on 03 Nov 2017]

38. Ribeiro AL, Pereira W. Spray drying conditions and encapsulating composition effects on formation and properties of sodium diclofenac microparticles. Powder Technol 2007;171:7-14.

39. Couto RO, Martins FS, Chaul LT, Conceicao EC, Freitas LA, Bara $\mathrm{M}$, et al. Spray drying of Eugenia dysenterica extract: effects of in-process parameters on product quality. Rev Bras Farmacogn 2013;23:115-23.

40. Gonnissen Y, Gonçalves SIV, De Geest BG, Remon JP, Vervaet C. Process design applied to optimise a directly compressible powder produced via a continuous manufacturing process. Eur J Pharm Biopharm 2008;68:760-70.

41. Vasconcelos EA, Medeiros MG, Raffin FN, Moura TF. Influência da temperatura de secagem e da concentração de Aerosil ${ }^{\circledR} 200$ nas características dos extratos secos por aspersao da Schinus terebinthifolius raddi (Anacardiaceae). Brazilian J Pharmacogn 2005;15:243-9.

42. Moreira GE, Costa MG, de Souza AC, de Brito ES, de Medeiros MdeF, de Azeredo HM. Physical properties of spray dried Acerola pomace extract as affected by temperature and drying aids. LWT-Food Sci Technol 2009;42:641-5.

43. Jangam SV, Thorat BN. Optimization of spray drying of ginger extract. Dry Technol 2010;28:1426-34.

44. Rowe RC, Sheskey PJ, Owen SC. AP Association, Handbook of pharmaceutical excipients. 6th ed. London; Chicago: Pharmaceutical Press; American Pharmacists Association; 2009.

45. Vehring R. Pharmaceutical particle engineering via spray drying. Pharm Res 2008;25:999-1022.

46. Aulton ME. Aultons pharmaceutics the design and manufacture of medicines. 3rd ed. Edinburgh New York, United States: Churchill Livingstone; 2007.

47. Callahan JC, Cleary GW, Elefant M, Kaplan G, Kensler T, Nash RA. Equilibrium moisture content of pharmaceutical excipients. Drug Dev Ind Pharm 1982;8:355-69.

48. Cano Chauca M, Stringheta PC, Ramos AM, Cal Vidal J. Effect of the carriers on the microstructure of mango powder obtained by spray drying and its functional characterization. Innov Food Sci Emerg Technol 2005;6:420-8. 